\title{
Esophageal Squamous Cell Papilloma
}

National Cancer Institute

\section{Source}

National Cancer Institute. Esophageal Squamous Cell Papilloma. NCI Thesaurus. Code C5344.

A rare neoplasm arising from the distal third of the esophagus. Morphologically, it is characterized by the presence of fibrovascular cores covered by mature stratified squamous epithelium. Progression to squamous cell carcinoma is extremely rare. 